\title{
Relevance Of Goodsall's Rule In Fistula-In-Ano
}

\author{
${ }^{1,}$ Dr. Krishna Kumar Mallick , ${ }^{2 .}$ Dr.Nilamri Bin Mohamed Kamil \\ ${ }^{I}$ Associate Professor, Dept. of surgery AIMST University, \\ ${ }^{2}$ Malaysia. Colo-rectal Surgeon, Hospital SultanahBahiyah AlorSetar, Malaysia. \\ Data compiled and references collected by following outgoing M.B.B.S. students of AIMST University:- \\ 1.Tan Shin Wuei, 2.Jolyn Ch'ngJhiaoRou, 3.Koh Ming Zhi, 4.Adrian choong Gian Shin, 5.Karen Tan Hui Hui.
}

\begin{abstract}
In the year 1900 David Henry Goodsall described a rule regarding relationship of 'external opening to the tract' in cases of Fistula-in-ano. According to Goodsall's rule 'if the external opening is anterior to the transverse anal line and within $3 \mathrm{~cm}$. from the anal verge, the internal opening will be in straight radial line. But, if the external opening is behind the transverse line or more than $3 \mathrm{~cm}$. from the anal verge, the internal opening will be at the posterior midline of the anal canal.'In such cases the tract will be a tortuous one. We tried to justify his postulation by analyzing about 70 patients of fistula-in-ano.
\end{abstract}

\author{
ABBREVIATION \\ IS-Internal sphincter \\ SM-Sub-mucosal external sphincterSF-Superficial external sphincter \\ $D E-D e e p$ external sphincterPR-Pubo-rectalis muscle \\ LA-Levatorani muscleFistula-Fistula-in-ano \\ Tract-Hollow trct of fistula
}

KEY WORD: Fistula, Tract, Internal and external openings.

\section{INTRODUCTION}

Fistula-in-ano is a hollow tract lined by granulation tissue and connects a primary opening inside the anal canal to a secondary opening in the perianal skin. It is almost twice as common in males as in females. Before proceeding to our study, we went through the related works done by Saino P. (1), Dennis F Zagrodnik (2), Steve Halligan (3), Belliveau P. (4), Cosman BC (5) and Rosen L. (6). Ross ST (7) and Cirocco WC (8) also did some significant work on fistula-in-ano. Parks et al analyzed about 400 cases at St. Mark's Hospital, London and classified fistula-in-ani into 4 groups.As there has been a rise in the conflicting data regarding the positive predictive value of the Goodsall's rule, we tried to analyze the cases as the correctness of the rule saves much time and money of the patient in investigations and management as well as help the surgeons to plan the surgery early.In a study done by Barwood et al (9) in 1997, it was revealed that the Goodsall's law was $91 \%$ accurate in cases of posterior opening and only 69\% in anterior openings.In another study done in 2001 by Gunawardhana PA and Deen KI (10) in 35 patients, it was found that Goodsall's law was correct only in 59\% of cases. Similarly, in 2005, Hirrranyakas et al's (11) study showed only $58.82 \%$ of accuracy of Goodsall's law.

[1] To study the validity of Goodsal's rule.

\section{OBJECTIVES}

[2] Applying the rule on the patient who is coming to the ward for fistula-in-ano management.

[3] Saving the cost of doing other invasive diagnostic method which could be a burden either to the patient or to the establishment.

\section{MATERIAL AND METHOD}

All the patients suffering from fistula-in-ano and admitted to the Hospital SultanahBahiyah, AlorSetar, Malaysia during 2010 to 2012 were selected for this study. They belonged to all age group and from both sex.

\section{EXCLUSION CRITERIA}

1. Patients, whose records were either lost or incomplete.

2. Complex fistula-in-ano. 
All the findings were recorded in tabular form .

Findings

Age group of fistula patients---.-

\begin{tabular}{|c|c|c|}
\hline Age in years & Number of patients & Percentage \% \\
\hline $1-20$ & 3 & 4.2 \\
\hline $21-40$ & 36 & 50.7 \\
& & \\
\hline $41-60$ & 25 & 35.2 \\
\hline $61-80$ & 7 & 9.9 \\
\hline Total & 71 & 100 \\
\hline
\end{tabular}

\begin{tabular}{|l|l|l|}
\hline Gender & Number of patients & Percentage \\
\hline Male & $\mathbf{6 0}$ & $\mathbf{8 5}$ \\
\hline Female & $\mathbf{1 1}$ & $\mathbf{1 5}$ \\
\hline Total & $\mathbf{7 1}$ & $\mathbf{1 0 0}$ \\
\hline & \multicolumn{2}{|l|}{} \\
\hline
\end{tabular}

\section{$\underline{\text { Sex incidence }}$}

$\underline{\text { Race incidence- }}$

\begin{tabular}{|l|l|l|}
\hline Race & Number of patient & Percentage \\
\hline Malay & 52 & 73 \\
\hline Chinese & 9 & 13 \\
\hline Indian & 8 & 11 \\
\hline Others & 2 & 3 \\
\hline Total & 71 & 100 \\
\hline
\end{tabular}

Intra-operative findings of fistula-in-ano-

\begin{tabular}{|l|l|l|l|}
\hline & Anterior opening & Posterior opening & Total \\
\hline Direct tract & 15 & 20 & 35 \\
\hline Indirect tract & 13 & 23 & 36 \\
\hline Total & 28 & 43 & 71 \\
\hline
\end{tabular}

\begin{tabular}{|l|l|}
\hline Position of opening & Percentage \% \\
\hline Anterior & 39 \\
\hline Posterior & 61 \\
& \\
& \\
\hline
\end{tabular}

Patients that followed Goodsall's rule-54\%

Patients that did not follow Goodsall's rule- $46 \%$ 


\section{v. DISCUSSION AND CONCLUSION}

The tabulated findings are self-explanatory. Out of 71 patients of fistula-in-ano admitted in Hospital SultanahBahiyah, Alor Setar, Malaysia from 2010 to 2012, 60 were male and only 11 females. Out of these only $54 \%$ patients with external opening anterior to the transverse anal line and $53 \%$ with posterior external opening complied with Goodsall's rule.Hence, it is quite evident that Goodsall's rule does not give us definite information regarding the tract or the internal opening. The rule, however, gives us a clue and we should proceed for other investigative tools before planning surgery for fistula-in-ano.

\section{REFERENCES}

[1] Sainio P. Fistula-in-ano in a defined population-Incidence and epidemiological aspect. 1984:73(4):219-24.

[2] Dennis F Zagrodnik II MD, FACS Consulting Staff, Premier Surgical of Wisconsin.

[3] Steve Halligan MD, FRCP, FRCR and Jaap Stoker MD, Ph.D. 10.1148/radiol.2391041043 April 2006.

[4] Belliveau P. Anal Fistula : Current Therapy in Colon and Rectal Surgery, Philadelphia.

[5] Cosman BC All's Well That Ends Well: Shakespeare's treatment of anal fistula. Dis Colon Rectum July, 1998: 914-24.

[6] Rosen L. Anorectal abscess-fistulae. SurgClin North Am. Dec. 1994: 74(6):1293-308.

[7] Ross ST. Fistula-in-ano. SurgClin North Am. Dec. 1988:68(6):1417-26.

[8] Cirocco WC. Reilly JC Challenging the predictive accuracy of Goodsall's rule for anal fistulas. Dis Colon Rectum. 1992 June: 35(6):537-42

[9] Barwood et al. Fistula-in-ano: A prospective Study of 107 patients. Aus NVJ Surg. 1997 Feb-March : 67(2-3):98-102.

[10] Gunawardhana PA, Deen KI University Dept. of Surgery, North Colombo General Hospital, Sri Lanka, ANZ J Surg. 2001 Aug. 71(8):472-4.

[11] Hirranyakas N, Maipang T, Greater A. (2005) Assessment of anal fistulas using endo-anal ultrasound .Songkla Med J 2005:23(5):357-361. 